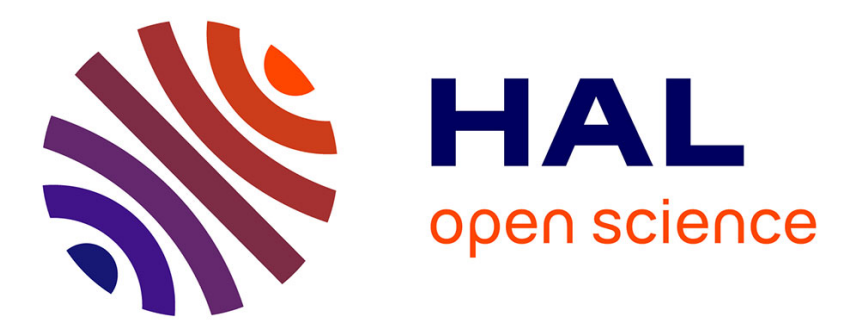

\title{
Natural hazards versus climate change and their potential impacts in the dry, northern Himalayas: focus on the upper Kali Gandaki (Mustang District, Nepal)
} Monique Fort

\section{- To cite this version:}

Monique Fort. Natural hazards versus climate change and their potential impacts in the dry, northern Himalayas: focus on the upper Kali Gandaki (Mustang District, Nepal). EnvironmentalEarth Sciences, 2014, [s.p.]. 10.1007/s12665-014-3087-y . hal-01201550

\section{HAL Id: hal-01201550 \\ https://hal.science/hal-01201550}

Submitted on 22 Sep 2015

HAL is a multi-disciplinary open access archive for the deposit and dissemination of scientific research documents, whether they are published or not. The documents may come from teaching and research institutions in France or abroad, or from public or private research centers.
L'archive ouverte pluridisciplinaire $\mathbf{H A L}$, est destinée au dépôt et à la diffusion de documents scientifiques de niveau recherche, publiés ou non, émanant des établissements d'enseignement et de recherche français ou étrangers, des laboratoires publics ou privés. 


\title{
Natural hazards versus climate change and their potential impacts in the dry, northern Himalayas: focus on the upper Kali Gandaki (Mustang District, Nepal)
}

\author{
Monique Fort
}

Received: 8 July 2013/ Accepted: 20 January 2014

(c) Springer-Verlag Berlin Heidelberg 2014

\begin{abstract}
In the Himalayas, the consequences of climate change are a fairly debated issue, mainly questioning the availability of water resources to the lowland population. North of the monsoon Himalayas, a semi-arid, continental climate prevails and settlements rely economically mostly on irrigated crops, high altitude rangelands, trade and tourism. The upper Kali Gandaki (Mustang) is situated in this area, with sharp contrasts between valley bottoms $(<3,000 \mathrm{~m})$ and high, glaciated peaks (up to $>8,000 \mathrm{~m}$ ). The impacts of climate change may appear in different ways. Gullying is common, and might increase with greater climate variability. Increased ground instabilities (earthflows and occasional debris flows) affecting extensive shale/marly substrates are also expected, linked to changes in snow cover and seasonality. Similarly, the combination of higher snowfall and rapid melting may favour the occurrence of flash floods. The possibility of glacial outburst floods is less probable because of the present limited glaciation. Eventually, permafrost melting may induce rock avalanches down the steepest cliffs and might impact the adjacent valley floors. Collectively, these hazards will affect irrigation canals and fields, new infrastructures and the associated growing settlements. Water availability in the near future is more difficult to predict; however, any change in the amount and nature of precipitation may affect groundwater reserves, hence spring discharge and runoff, with consequences for agricultural products. Eventually, the overall potential increase in natural hazards may jeopardize the development of small markets and the
\end{abstract}

M. Fort $(\square)$

CNRS UMR 8586 PRODIG, Université Paris Diderot,

Sorbonne-Paris-Cité, 5 rue Thomas Mann,

75205 Paris Cedex 13, France

e-mail: fort@univ-paris-diderot.fr good connection of these upper valleys to the main urban centres of Nepal, a country with a very low economic and social capacity to adjust.

Keywords Himalayas of Nepal - Arid uplands - Climate change $\cdot$ Natural hazards $\cdot$ Mustang District

\section{Introduction}

The glaciated peaks of the Tibetan plateau and surrounding mountain ranges, such as the Himalayas, make the entire central Asian mountains the water towers of Asia (Messerli and Ives 1997), which supply more than two billion people living in very large cities or in irrigated areas of adjacent lowlands (Immerzeel et al. 2010; Singh et al. 2011; Miller et al. 2012). In this context, the decline of glaciers (Dyurgerov and Meier 2005) and its consequences on natural hazards and water resources have become of great concern in recent decades (Mool et al. 2001; Kappenberger 2007; Bajracharya and Mool 2009; Immerzeel et al. 2010) with a specific focus on the accelerated retreat of glaciers causing moraine-dammed lakes to form, hence posing potential outburst flood hazards (ICIMOD 2011). Glacier recession is considered the best evidence of climate warming, despite a few exceptions like in the Karakoram where glacier expansion confined to the highest relief glaciers has been recorded (Hewitt 2005). In fact, climate warming remains a fairly debated issue in the Himalayan regions, with its consequences that may have been largely exaggerated, especially on the southern, monsoon side of the Himalayas. Several models with different outcomes, depending on the primary data and scaling methods utilized, have been applied along the 2,500-km-long Himalayan range and adjacent areas, and their results suggest a clear trend 


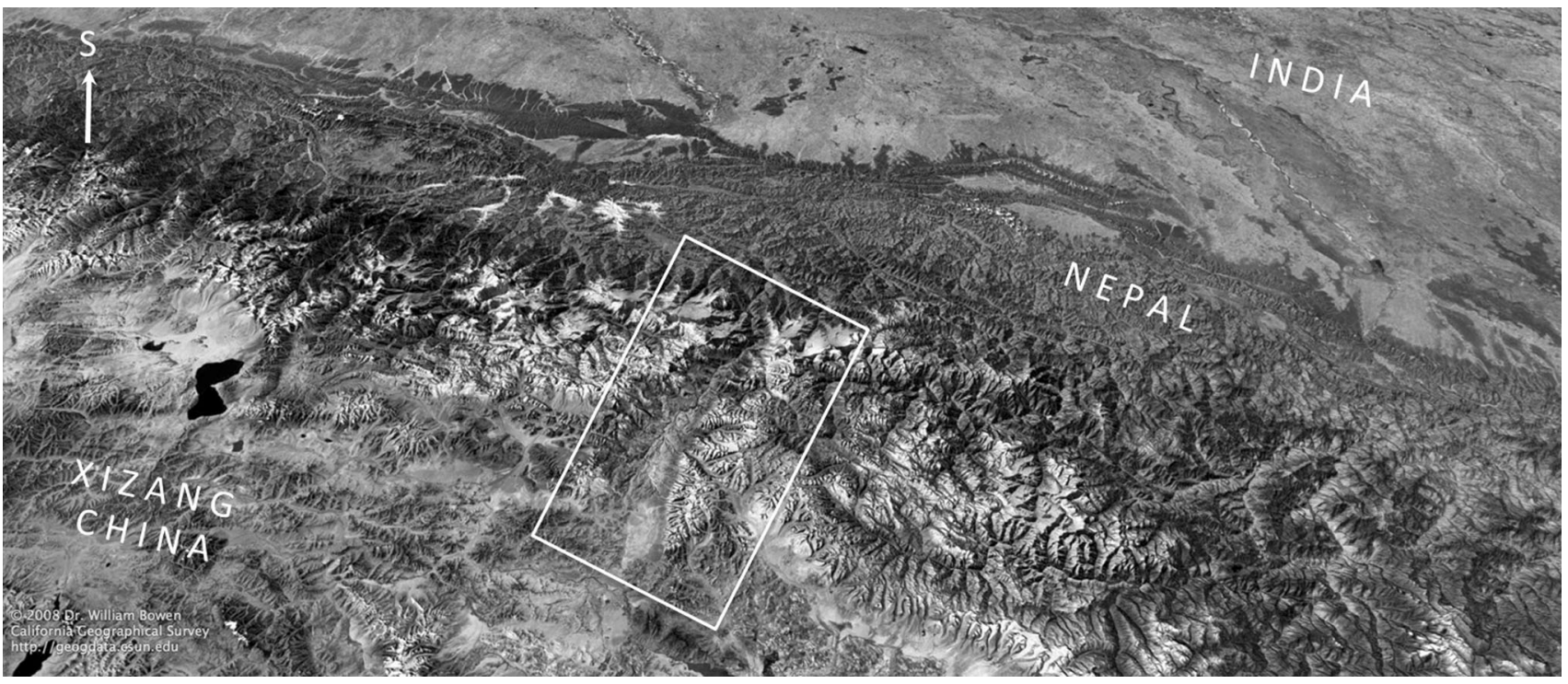

Fig. 1 The Central Himalayan range of Nepal viewed from the north. The Mustang area lies in the lower, central part of the photo. It is drained by the Kali Gandaki River, a major affluent of the Ganges

towards warming, but this still has to be checked with field data (Immerzeel et al. 2013).

Climate warming seems to be a reality in most parts of Central Asia (New et al. 2002; Kundzewicz et al. 2014; Lioubimtseva 2013). Average temperatures in Tibet may have risen by as much as $0.9^{\circ} \mathrm{C}$ since the 1980s. Higher warming rates $\left(0.03-0.07{ }^{\circ} \mathrm{C}\right.$ per year) have been observed in the central Himalayas and the whole of the Tibetan Plateau (Singh et al. 2011), and average temperature increases of $0.025{ }^{\circ} \mathrm{C}$ per year have been recorded around glaciers in the Dhaulagiri Himal (Shrestha and Aryal 2011). The nature (rainfall, snowfall), amount $(<300 \mathrm{~mm} /$ a) and seasonality of precipitation have also been considered, resulting in more uncertainty about their evolution and hence their impacts (Bookhagen and Burbank 2010; Thayyen and Gergan 2010; Miller et al. 2012). Nevertheless, the latest general circulation models (GCMs) project a greater increase in precipitation (Immerzeel et al. 2013). In fact, insufficient long-term in situ observations and complex topographic conditions pose major problems for quantifying the magnitude of climatic trends, mostly due to differences in topography and microclimatic regimes (Kattel and Yao 2013). Whatever their shortcomings are, all approaches confirm climate warming, a trend which in the driest, unglacierized parts of the northern Himalayas may have specific impacts, such as a decrease in water resources for irrigation and rangelands, upon which the survival of populations living in these remote places depends.

This contribution focuses on the impacts that climate change might have on natural hazards such as gullying and
River, separating the Annapurna Himal on the left from the Dhaulagiri Himal on the right (@2008 William Bowen)

mass wasting in the arid Himalaya. First, the specificity of the central part of the northern Himalayas, i.e. the Mustang area in central Nepal, is presented and then the types of hazards that may increasingly arise from climate change, and potentially threaten the population and their current efforts to develop infrastructures and new sources of income, are illustrated (Fig. 1).

\section{The study area}

The focus of this contribution is the upper Kali Gandaki valley, which corresponds to the northern Mustang District of Nepal. Located north of the Annapurna (8,091 m) and Dhaulagiri $(8,172 \mathrm{~m})$ ranges, the area falls on the rainshadow side and is relatively protected from monsoon influences. In contrast with environmental problems that may arise in the southern "wet" Himalaya (Bahadur 2012), Mustang is quite representative of the Trans-Himalayan zone characterized by a semi-arid, continental climate, hence by significant temperature variability amplified by elevation contrasts (Fig. 2). There is a marked, northward declining gradient in precipitation in Marpha $\left(28^{\circ} 45^{\prime} \mathrm{N}-\right.$ $83^{\circ} 42^{\prime} \mathrm{E}, 2,695 \mathrm{~m}$ asl.), annual precipitation is around $400 \mathrm{~mm}$ decreasing to below $300 \mathrm{~mm}$ in Jomosom $\left(28^{\circ} 47^{\prime} \mathrm{N}-83^{\circ} 43^{\prime} \mathrm{E}, 2,740 \mathrm{~m}\right.$ asl.), then below $160 \mathrm{~mm}$ in Lo Mantang $\left(29^{\circ} 10^{\prime} \mathrm{N}-83^{\circ} 57^{\prime} \mathrm{E}, 3,800 \mathrm{~m}\right.$ asl.). Inter-annual variability is high, for example in Lo Mantang with "wet" years such as $1978(298 \mathrm{~mm})$ in contrast with very dry years as recorded in $1982(85 \mathrm{~mm})$. Snow precipitation prevails during wintertime and at an elevation above 

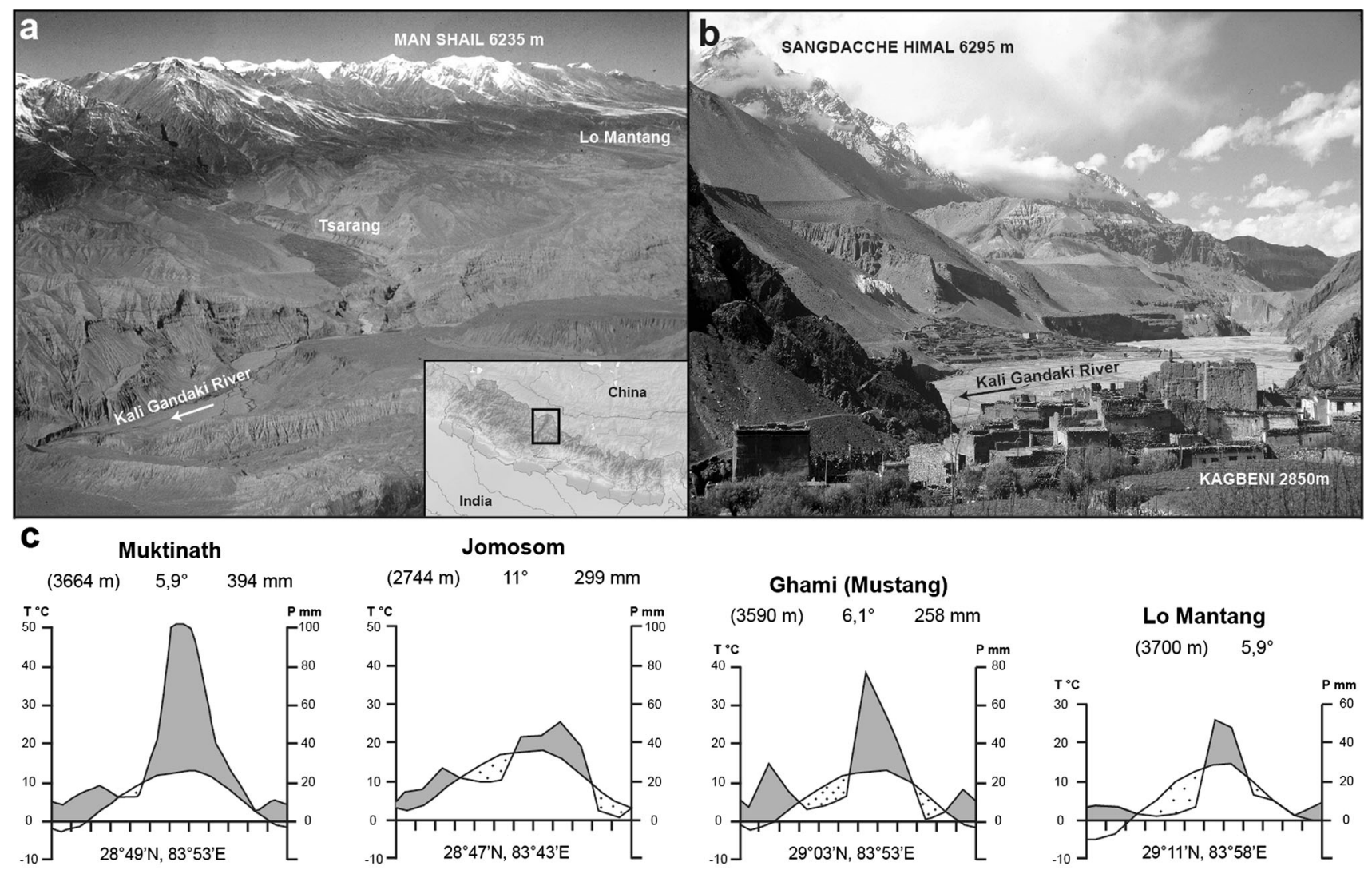

Fig. 2 a The arid, upper Mustang area, located on the northern, rainshadow side of the Himalayas: structurally controlled, the ThakkholaMustang graben offers only limited sites for villages, i.e. the Late Quaternary terraces overlooking the Kali Gandaki canyon (ㄷ1978 M. Fort); b The upper Kali Gandaki north of Jomosom (Mustang District, Nepal) is marked by high relief and violent winds. Note the absence of continuous vegetal cover and the extensive irrigated fields of Kagbeni and Tirigaon (2,800 m, middle ground) (2009 M. Fort); c the precipitation-temperature diagrams reflect a dominant aridity (stippled area, dry season; grey areas, wet season) and a complex

seasonality, influenced by a continental character and elevation; elevation in metres asl., annual mean temperature, and mean annual precipitation are given for each station. Muktinath is in the upper valley of Kagbeni, Jomosom is $10 \mathrm{~km}$ south of Kagbeni, Ghami is just on the left of the photo (a). Note that these meteorological data, collected from the Department of Hydrology and Meteorology, Government of Nepal, are only estimations established in selected years with reliable records (Diagrams adapted and redrawn from Dobremez 1976; Fort 2000a; Miehe et al. 2002)

2,500 m, but exceptional snowfall can occur at any time of the year. Spells of summer rainfall are not rare, whereas characteristic, strong valley winds have a severe desiccating effect, reinforced by sharp, topographic contrasts over a very short distance between valley bottoms $(<3,000 \mathrm{~m})$ and high glaciated peaks (Fig. 2) (Fort 1996; Fort 2000b).

The vegetation cover is affected by this northward trend in aridity. Near Marpha, Pinus wallichiana forms dense forests, whereas going further north the vegetation altitudinal belt narrows due to both dryness (downslope) and coldness (upslope). It ranges from an open forest of cedar trees (Cupressus torulosa) in the south to a xerophytic Caragana gerardiana ("porcupine heath") steppe with Juniperus indica in the north (Dobremez and Jest 1971; Dobremez 1976; Miehe 1984; Miehe et al. 2002).

The exceptionally harsh environment and dissected topography of Mustang make the geo-ecological conditions of irrigation and the potential natural hazards particularly

severe (Fort 1987; Fort 2000a). The growing season is short and does not allow more than one crop per year (buckwheat, wheat, naked barley). Population density is low, with fewer than 5 inhabitants $/ \mathrm{km}^{2}$. Settlements are generally located either on Quaternary, Late Glacial or Holocene terraces along the Kali Gandaki valley or on alluvial fans at junctions with tributary torrential streams (Fig. 2). However, some villages are settled in upper tributary valleys, shaped into dark shales of the folded Mesozoic series, a substrate predominant in the eastern part of upper Mustang and most prone to landsliding (Fort et al. 1982).

Archaeological findings indicate that this region (and more specifically the Jhong valley east of Kagbeni) was already inhabited and cultivated several millennia B.C. (Schuh 1992-93; Pohle 1993; Simons and Schön 1998; Baade and Mäusbacher 2000; Knörtzer 2000). The traditional livelihood of the Loba (inhabitants of Mustang) was 
Fig. 3 Conceptual diagram presenting the main components of the Mustang area, the irrigation system, and the zones most exposed to natural hazards. Five belts are identified (glaciers and high mountains, slope scarps, glacio-fluvial terraces, steep cliffs and the valley bottom of the Kali Gandaki River). The vertical section is not to scale (modified from Fort 2000a)

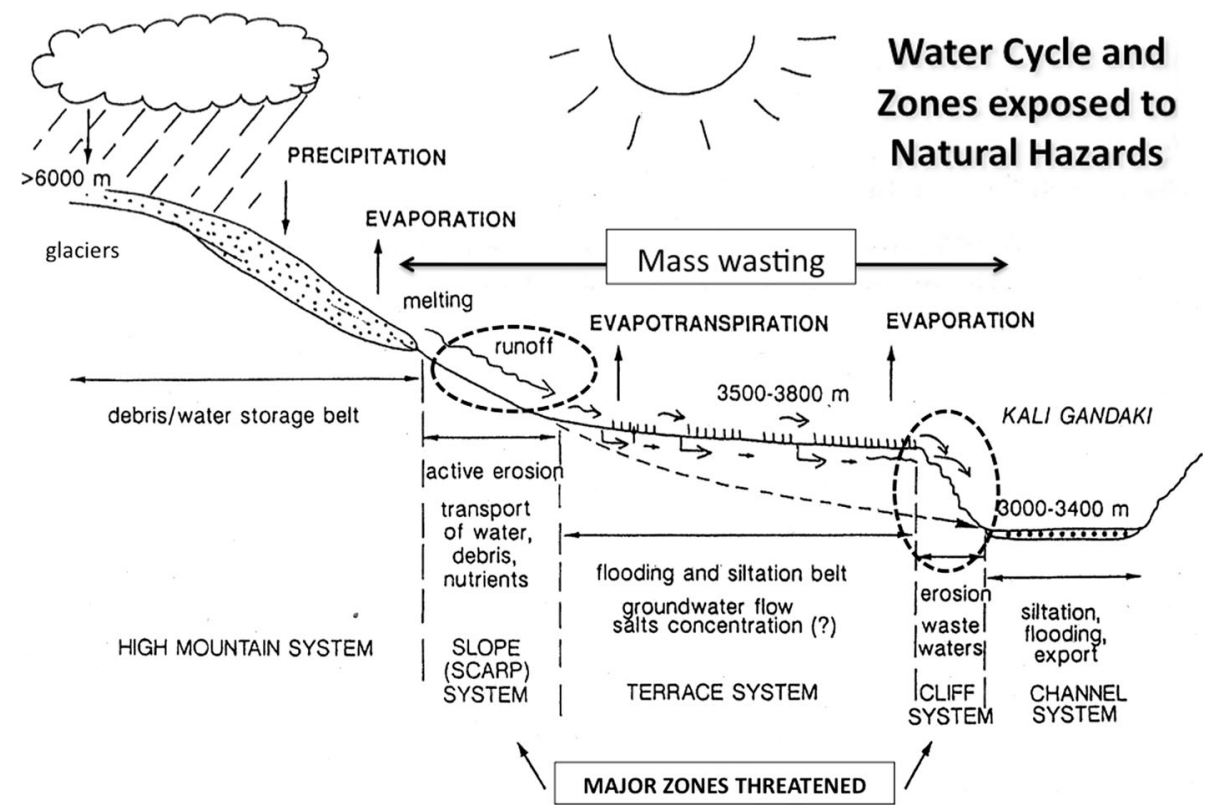

hazards and, despite the uncertainty of the available scenarios on future climate change, it is worth understanding how changes in different parameters may affect the landform subsystems. In the following lines we will concentrate mostly on natural hazards, and try to assess the cost and benefits which could result from a change in climate conditions.

\section{Methods}

Most of the investigations were carried out in southern Mustang during different seasons, with many visits between 1974 and 2009, and a recent visit in 2013, whereas upper Mustang (upstream from Kagbeni) was visited twice in 1993 and 1994. Following field observations, careful mapping of the geomorphology (including geology, superficial soils and active processes) of the southern part of Mustang was completed in 1983, within the framework of the RCUP (Resource and Conservation Utilization Project) (Fort 1987). Repeated photographs together with aerial photos and satellite images, interviews with local people and discussions with scientists from different fields helped appreciate the nature of the changes in climate parameters and the varying perceptions of these changes according to places and people.

\section{Natural hazards}

The question is to know whether climate change, hence changes in the water budget, may increase or slow down natural hazard development. Climatic parameters control to 


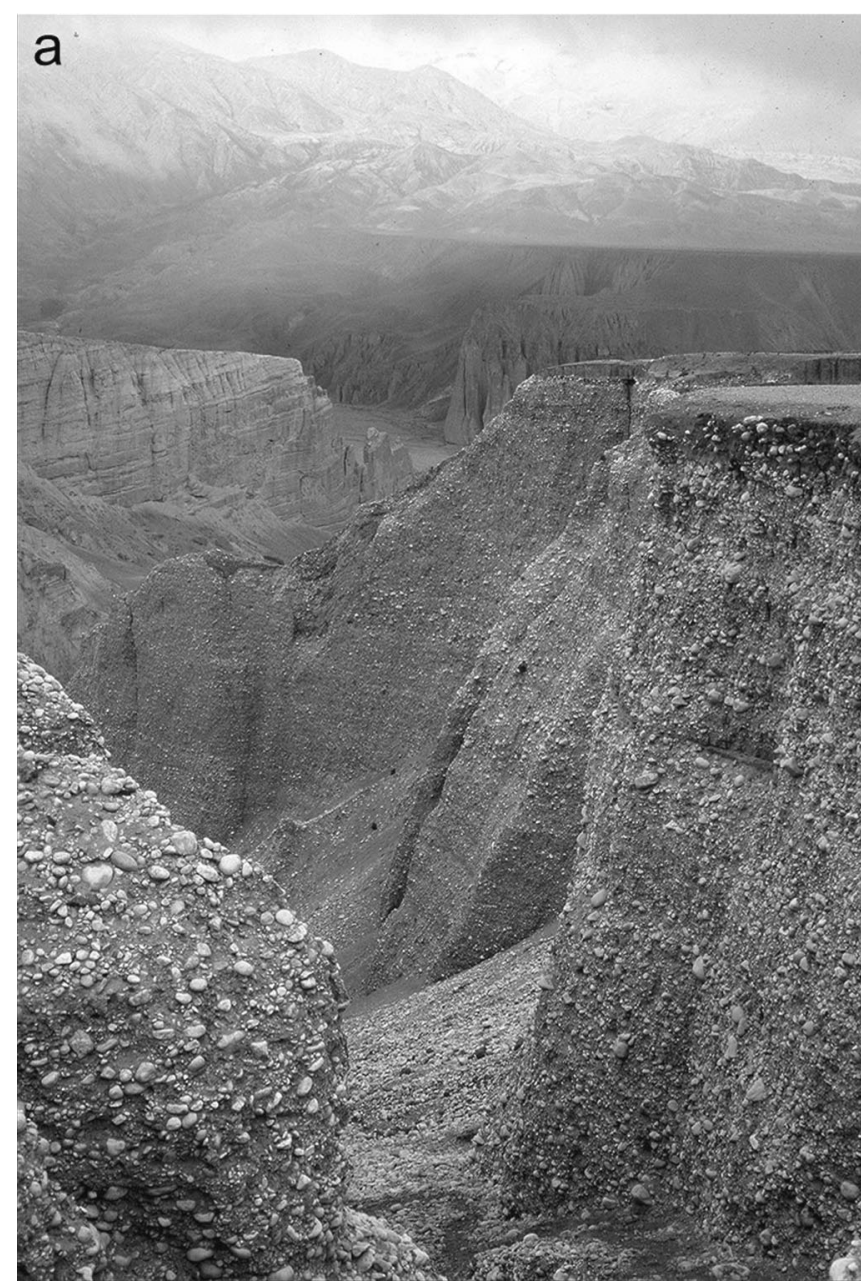

Fig. 4 The upper Mustang valley is characterized by vertical incision from the Kali Gandaki River, caused by retrogressive erosion that affects an 80-km-long section upstream of lower Mustang. a easternmost cultivated part of Tsarang terrace $(3,500 \mathrm{~m})$ with current loss of

a large extent the different types of geomorphic hazards: gullying, mass-wasting dynamics, flash floods, glacial lake outburst floods. Each of these processes is considered below.

\section{Gullying}

Dramatic, headward erosion and incision encroaching over terrace edges from the Kali Gandaki River along its major tributaries (Fig. 4b) is in progress due to the readjustment of the longitudinal profile of the river after deglaciation (Fort 1996, 2000b). Pulses of gullying are observed during the melting season (spring) and during rain/hail storms during summer. This process results in a significant loss of irrigated perimeters as observed in upper Mustang near Tsarang (Fig. 4a). Similarly, ongoing active gullying affecting marly and shale deposits of the Mustang graben filling is a direct threat to the settlements and fields below (Fig. 4c). Gullying may interrupt irrigation canals, and

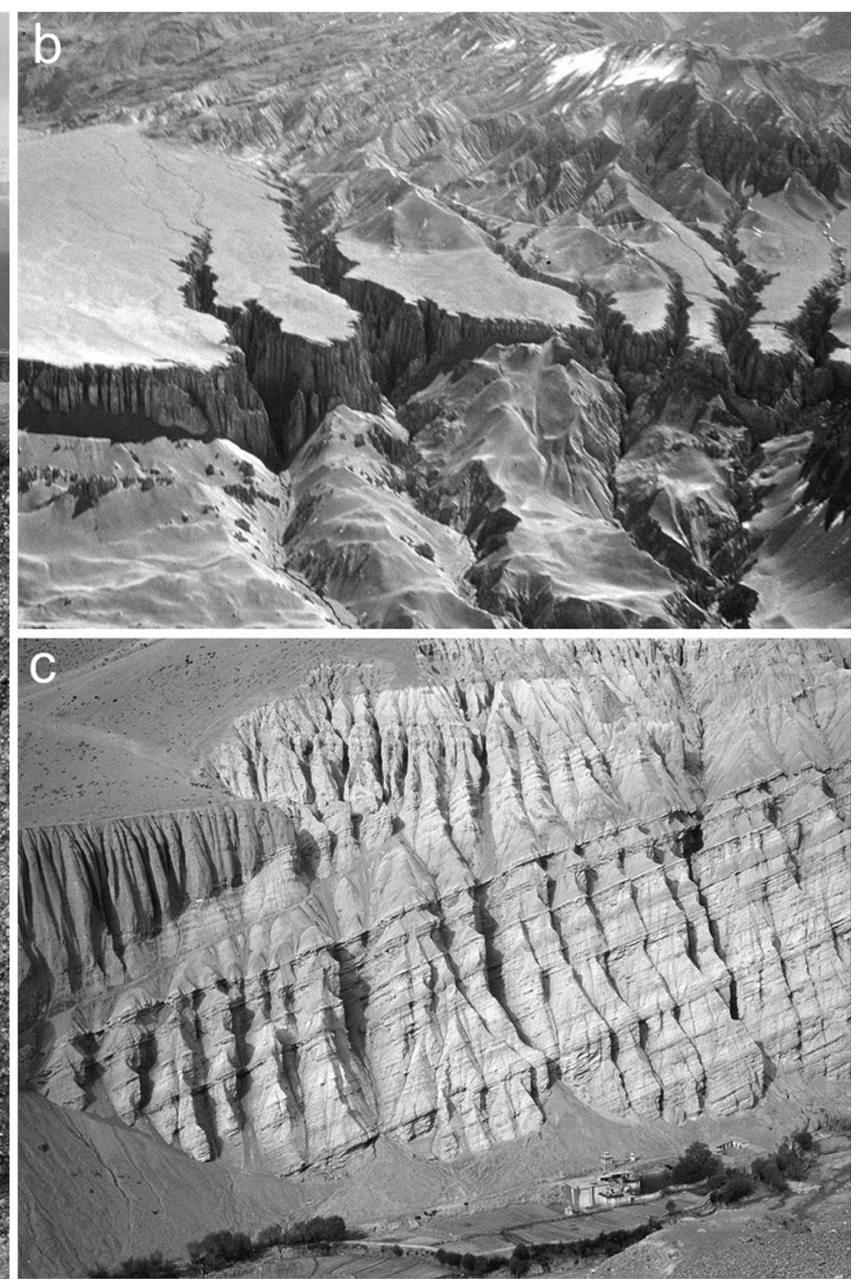

irrigated fields developed on the terrace top; b left-bank terraces of the Kali Gandaki affected by headward erosion; c ongoing active gullying of the cliff directly threatening a farm and a temple settled beneath (all photos (C)1993 M. Fort)

indirectly lead to the abandonment of irrigated perimeters, hence of entire villages, as observed along the Tetang khola below the trail going up to Tangbe (Baade et al. 1998) or along the small tributary of Ghami (Fort 2000a), or at Phudzeling following the destruction of the irrigation canal uptake by the incision of the Jhong khola along its right bank, as discussed below.

\section{Mass wasting}

Ground instability is very common along shale slopes (especially in the vicinity of Muktinath), with two major processes depending on the orientation of the slope vis-àvis the general dip of the geological series, slumps prevail on counter-dip slopes, whereas earthflows predominate on dip slopes (Fig. 5a). In addition, the general pattern of east-west flowing tributary valleys of the Kali Gandaki favours contrasted aspects (sunny vs. shady slopes) 

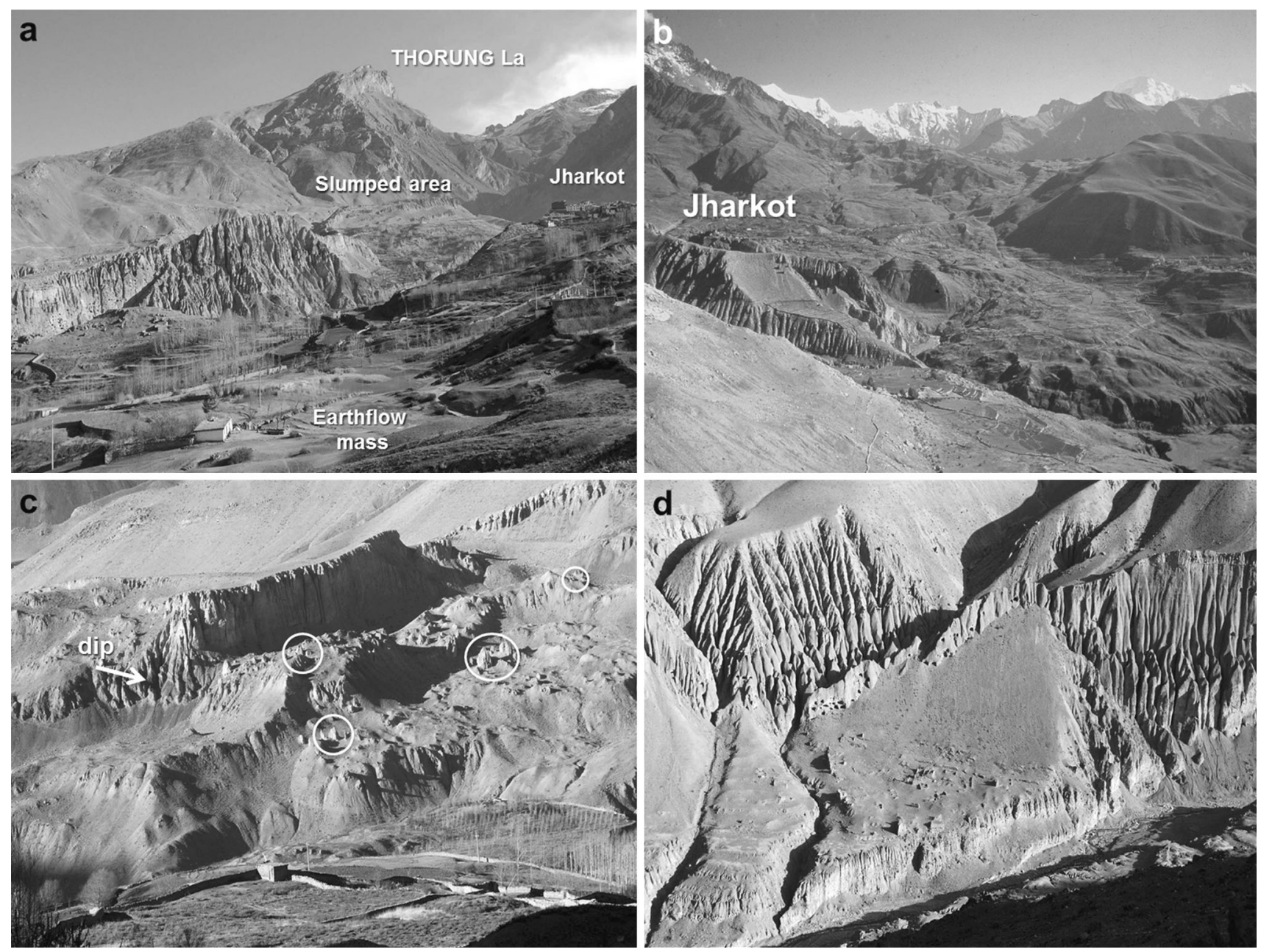

Fig. 5 Mass-wasting processes and their threat to settlements in the Jhong valley: a general view of the upper valley, with slumps and earthflows controlled by geology and dip (ㄷ2009 M. Fort). b Large complex slump-earthflow west of Jharkot and Muktinath (C1993 M.

between the two sides of the valleys as observed in the Jhong-Muktinath, Tetang, Yara and Tsarang valleys (Fort et al. 1982; Fort 2000a; Bernet 2012b); this last parameter controls the water amount and conditions seasonally (such as liquid, or snow or ground ice).

Along south-facing slopes, slumps are the major type of landsliding, with the slope appearing as a series of large tilted steps limited upslope by arcuated headscarps and cracks that facilitate the deep penetration of water and the mass movement downslope towards the river. The example provided in Fig. 5a extends to the lower slopes below the Phurkung Himal (6,482 $\mathrm{m}$ asl.); the farmers of Chhenger village $\left(28^{\circ} 49^{\prime} \mathrm{N}-83^{\circ} 51^{\prime} \mathrm{E}, 3,575 \mathrm{~m}\right.$ asl.) have to struggle to maintain their main irrigation canals striking across the slope to avoid their disruption, and eventually the abandonment of the site as occurred in the past further down in the same valley (Fig. 5c, d). Plastic tubing is now
Fort). c Ancient village destroyed by an active, slump landslide (right bank of the Jhong khola) (@2009 M. Fort); d remains of the terraced field system and abandoned village of Phudzeling (3,000 m asl., right bank of the Jhong khola) (C2009 M. Fort)

commonly used to cross either landslide scars and/or intermittent gullies in order to prevent any interruption of the water supply.

Along north-facing slopes, where snow cover may last several months during wintertime, rapid melt in spring may saturate the substrate, hence triggering the complex slumpearthflow as observed in the Jhong (Muktinath) valley, between Jharkot village and the Khyingar site (Fig. 4). This mass movement is active, expanding slowly yet continuously upslope, whereas the lower part of the mountain slope is the most active in relation to the incision of the Jhong khola stream, exporting the material at the toe of the earthflow and thus maintaining a continuous flux of material downslope. The movement towards the riverbed, as estimated by Baade et al. (1998) is not insignificant $\left(33 \mathrm{~m}^{3}\right.$ per year, a volume related to the width per metre of the upslope scar) but does not prevent cattle grazing. 
The initiation of this landslide is a debated issue. According to Miehe et al. (2009), the landslide occurred possibly due to the loss of forests, the mass movement started after a forest fire, as attested by pollen and charcoal analysis in connection with earlier settlements nearly 7,000-year old (Schuh 1992-93) whose inhabitants burnt the pine forest to start buckwheat cultivation. Thereafter, mass movements became a predominant factor of relief development (Baade and Mäusbacher 2000). Alternatively, we consider that the instability may have pre-existed due to favourable physical factors as mentioned above. The fact that the vegetal cover no longer exists is definitely an aggravating factor, which may be amplified by recent climate trends; first, desiccation of the shales favouring crack expansion in the soils during dry seasons, in turn favouring the deep penetration of water then increasing pore pressure, and thus the downslope movement in a positive feedback loop. This situation presents several outcomes; on the one hand, the persisting moisture in the shale bedrock favours pastureland and cattle activities during winter and summer periods, because the soil moisture content is sufficient for meadows to grow naturally (Fig. 3, Muktinath station). On the other hand, the recent construction of a road up to the Muktinath temples and the associated growth of settlements may both be threatened by the movement of the slope, in contrast to traditional foot trails (lower right corner) that can adjust well to ground mobility (Fort 1987, 1999). Despite the cracks affecting buildings, the local people are not deterred from developing new settlements.

Furthermore, on both sides of the valley slope instability is amplified and controlled at the toe by river incision. In fact, the active earthflow forces the deflection of the river, which in turn favours the incision and undermining of the opposite right bank by the Jhong khola. It was probably such a process that contributed to the destruction of the irrigation canal uptake and ruined the well-developed system of terraced fields of the ancient village of Phudzeling (Fig. 5d), even though political causes may also have led to the abandonment of the site (Simons et al. 1997).

In a context of increasing aridity, it can easily be predicted that open cracks may develop even deeper in this shale material on both slopes of the valley, hence favouring deeper water penetration and subsequent downslope movement. Additional runoff due to either rapid snowmelt in spring or to an abundant and intense precipitation event during summer may accelerate river incision, which in turn will significantly amplify slope movements and potential destructions.

Flash floods and debris flows

Flash flood and debris-flow hazards are rather common in these arid mountain streams. Despite their seasonal functioning, these streams have a regime characterized by a marked winter minimum (frost) in contrast to a late spring/ summer maximum (snow followed by glacial and/or permafrost melting). Amplified by the local topographical configuration, i.e. steep slopes (Fig. 3), and by the soft sediments composing the Thakkhola-Mustang graben (Fort 1996), these upper mountain catchments may be subject to extreme debris-flow events triggered by either intense rainstorms or accelerated snowmelt. Additional debris supply by mass movements, such as in the Narsing khola (Fig. 6a), together with the local deterioration and thaw of frozen ground at higher elevations (Fig. 6b), may contribute to triggering catastrophic debris-flow events, all the more damaging as the flows are funnelled by narrow, gorge sections before debouching onto confluence fans at the junction with the Kali Gandaki valley. This is particularly well-illustrated in the lower part of Mustang from Kagbeni southward, where most torrential fans are very active (fed by high glacierized peaks) hence preventing any efforts to stabilize them, as on the Dumba khola fan south of Jomosom (left bank) collecting waters from the snowy and glacial upper slopes of the Nilgiri mountains (Nilgiri North Peak 7,061 m asl.). South of Marpha, a dramatic debris flow affected the fields and orchards of the Nepal Government Experimental Farm (Gurung 1980) in 1973: proper embankments reinforced by tree plantations were implemented with success (Fort 1987). Further downstream, south of Tukuche $\left(28^{\circ} 42^{\prime} \mathrm{N}-83^{\circ} 38^{\prime} \mathrm{E}, 2,600 \mathrm{~m}\right.$ asl. $)$, recurrent damaging debris flows originating from a small, yet very steep catchment have required the building of protective structures such as embankments (the new motor road crosses this valley), which soon became, in a context of increasing and irregular rainfall, fairly useless. In fact, the active channel width had been reduced too much so that it was undersized to accommodate events of this type (Fig. 6b). Actually, the embankments were recently destroyed by a flood and no longer existed in 2013.

Impacts of glacial retreat?

In the late 1980s, a devastating glacial lake outburst flood (GLOF) occurred from the west side of the Mustang valley and destroyed many houses and fields (Fig. 7c, d), killing several people and cattle and ruining high pasture meadows (Fort 2000a). The source area lies on the northeast side of the glacierized Man Shail peak (6,268 m asl.) and the flood propagated through successive pulses along the Kali Gandaki valley down to Jomosom. The reason for this catastrophe is still not entirely clear as there was no eye-witness of the upstream development of the event. Of the two options, a landslide dam and/or a morainic dam, the second one seems the most probable, as a breached, frontal morainic crest is still visible in the upstream part of the valley 

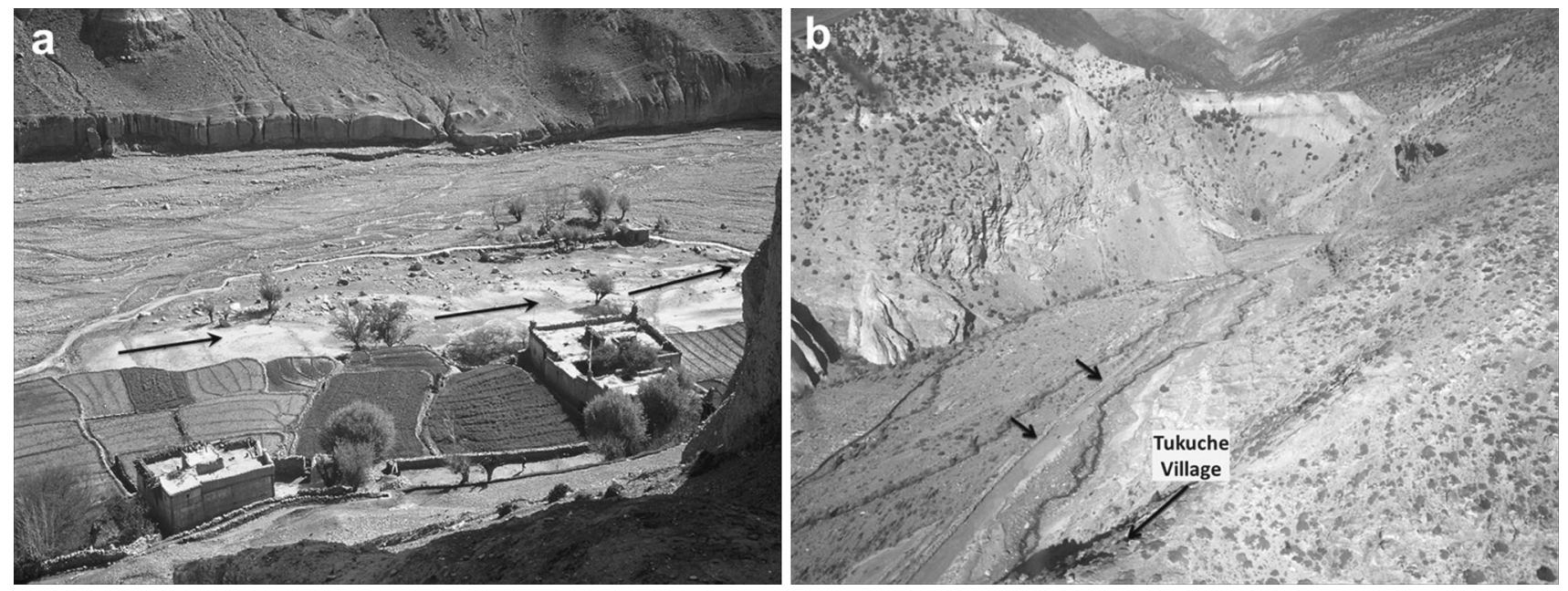

Fig. 6 a Impacts of debris-flow and flash flood events (arrows) across irrigated fields of an isolated farm, in Narsing khola, Upper Mustang (C1993 M. Fort); b Debris-flow channel and its control by embankments (arrows), west and upstream of Tukuche (C2009 M. Fort)

of Garphu $\left(20^{\circ} 13^{\prime} \mathrm{N}, 83^{\circ} 58^{\prime} \mathrm{E}, 3,910 \mathrm{~m}\right.$ asl.), north of Lo Mantang (Kappenberger 2007). The context of this disaster seems to be related to temperature rise and lake formation, yet the trigger of the breach is still unknown and might be related to the vicinity of the moderately active Thakkhola fault bordering the Mustang depression to the west (Fort et al. 1982). The possibility of a GLOF occurring again cannot be entirely ruled out, although the limited glacial cover does not seem to provide the right conditions for it.

\section{Discussion}

Several questions arise when trying to assess the impacts of climate change in the arid Himalaya. What are the projections of the future climate in the Nepal Himalayas? What would be the impacts of future climate on natural hazards? What would be the interactions between climate change, natural hazards and land use change in Mustang?

\section{Climate trends}

According to Shrestha and Aryal (2011), temperature data collected from the mid-1970s in the different stations of Nepal indicate that the average temperature between 1977 and 1994 increased at a rate of $0.06{ }^{\circ} \mathrm{C}$ per year, with a greater rise in temperature at higher altitudes (0.03-0.07 ${ }^{\circ} \mathrm{C}$ per year; Shrestha 2009). Increases in temperature were more pronounced during the cooler months (0.06-0.08 ${ }^{\circ} \mathrm{C}$ per year from October to February, for all of Nepal) than in the warmer months $\left(0.02-0.05{ }^{\circ} \mathrm{C}\right.$ per year for March-September, for all of Nepal) (Singh et al. 2011). In addition, the mean annual temperature is projected to increase by $1.3-3.8^{\circ} \mathrm{C}$ by the $2,060 \mathrm{~s}$, and by $1.8-5.8^{\circ} \mathrm{C}$ by the 2090s (McSweeney et al. 2010). Note that an increase in temperature will influence the conditions of permafrost distribution, and will also impact the nature and intensity of precipitation (less snow and more rain) and reduce the duration of the snow cover.

Nevertheless, and according to Singh et al. (2011), the trends in data observed for precipitation are more difficult to summarize succinctly since precipitation is extremely variable, the spatial coherence is poor, and there is a lack of series of long-term records. Despite their uncertainty, projections of mean annual rainfall averaged over Nepal from different models are broadly consistent in indicating increases in rainfall with seasonal differences. More specifically, summer (JJA) rainfall is projected to change by $-36 \mathrm{~mm}(-22 \%)$ to $+224 \mathrm{~mm}(+104 \%)$ per month by the 2,090s, with rainfall increases largest in the southeast of Nepal (McSweeney et al. 2010). In this scenario, however, little is said about the possible northward reinforcement of the summer monsoon influence, and how far to the north the monsoon influence will be active in the Kali Gandaki valley. Su et al. (2013) mention that in the last 38 years $(1970-2006)$, the Lete station $\left(28^{\circ} 38^{\prime} \mathrm{N}-\right.$ $83^{\circ} 35^{\prime} \mathrm{E}, 2540 \mathrm{~m}$ asl.) in southern Mustang has shown a pronounced rainfall increase in comparison with Marpha and Jomosom, and suggest that there might be a link between increasing rainfall and decreasing snowfall in the Mustang region. On the other hand, increasing aridity in northern Mustang due to the reduction in snowfall amount and snow cover duration is a risk that should not be ruled out, more specifically on south-facing slopes, where the drying out may be amplified by increasing wind in dry years. 


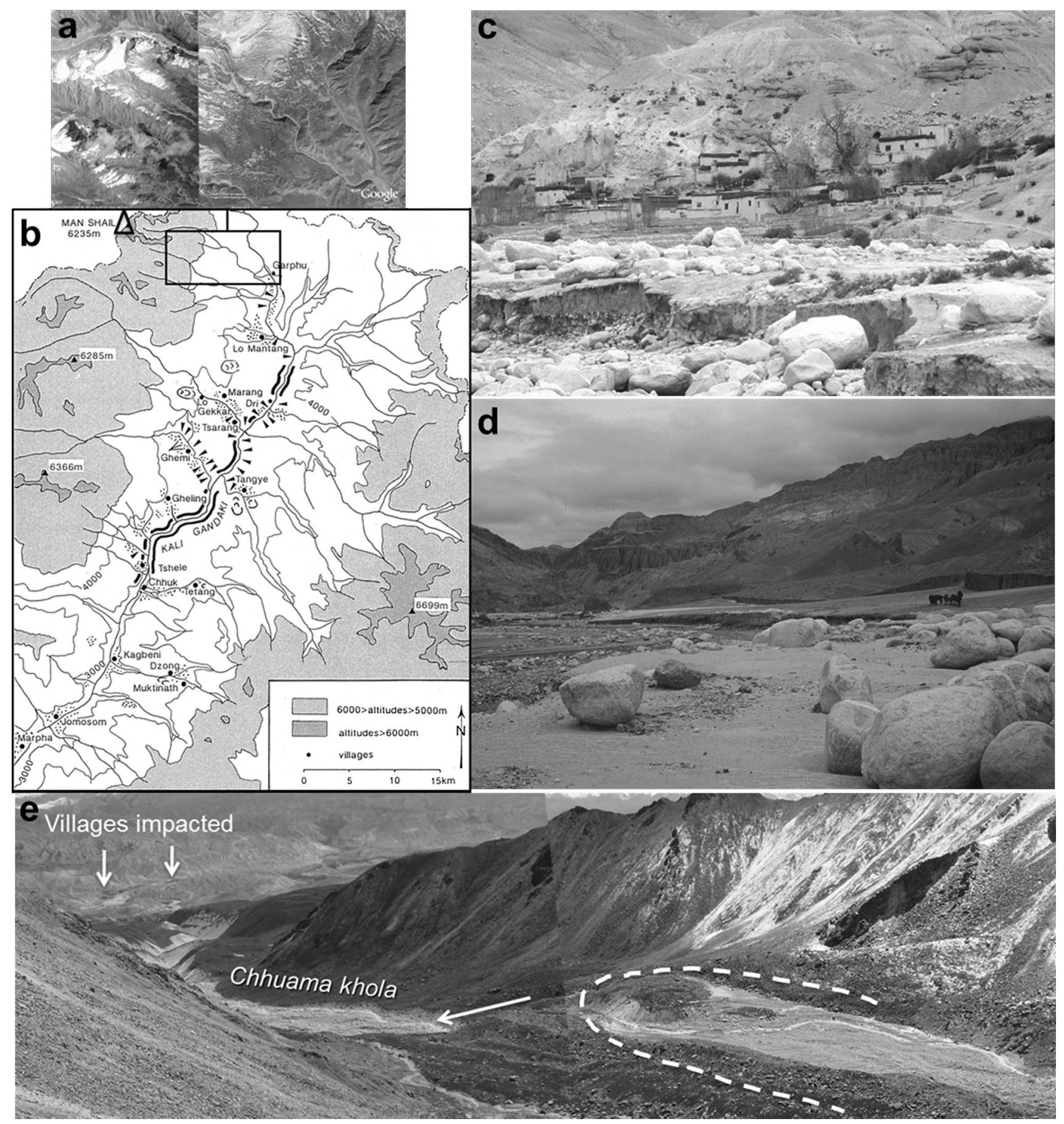

Fig. 7 1988-89 GLOF impacts in the upper Mustang (Nepal). a The source area can be seen on the Google Earth photo and $\mathbf{b}$ the flood propagated across the mapped area down to Jomosom (map modified after Fort 2000a); c Coarse $\left(>\mathrm{m}^{3}\right)$, very destructive boulders were abandoned a few kilometres downstream near Garphu (1993 M.
Fort), whereas in $\mathbf{d}$ coarse granitic sands were carried more than $50 \mathrm{~km}$ downstream (@1993 M. Fort); e remnants of the morainic ridge breach out, and eroded banks of the Chhuamakhola (다일 Kappenberger)

dammed lakes which might cause catastrophic floods impacting irrigated lands again. Yet the steep slopes of the Nilgiri and East Dhaulagiri mountains do not provide particularly suitable conditions for the formation of
With rising temperature we could expect continued glacier melting and the potential development of new moraine- 


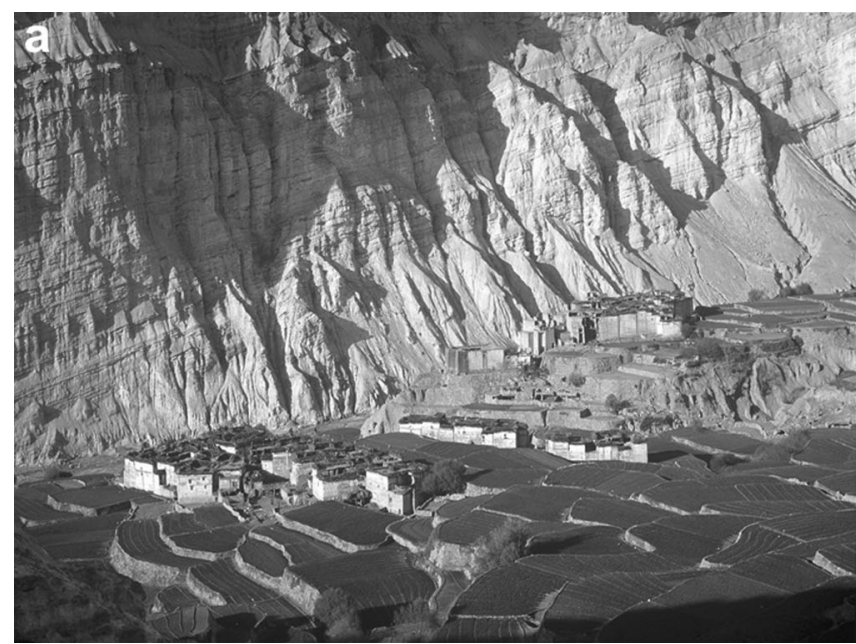

Fig. 8 a Traditional Tetang village relying on irrigation and a trade economy. Note how the packed houses are adapted to the high mountain environment, and how well-maintained the buckwheat and naked barley fields are. The nearby road of the Kali Gandaki valley may help promote this cultural heritage (1993 M. Fort); b Pangling

moraine-dammed lakes, in contrast with what is observed in eastern Nepal, where upper glaciated valleys are flatter (Bolch et al. 2008; Fujita et al. 2013). However, in Mustang, the disappearance of the smallest glaciers would eventually decrease the runoff water and more generally reduce the water supply to villages and terraces with their irrigated fields. This may also lead to springs drying up, imposing stress upon local consumption. However, groundwater storage is difficult to measure in such a remote mountainous terrain (Bookhagen 2012); collecting hydro-meteorological data sets is not easy, water-management agencies do not directly operate there and hence no data are readily available. Nevertheless, the water crisis in the Samzung village (northeast of Lo Mantang) recently led experts to recommend relocation of the settlement as the only appropriate response to assure water availability, at least in mid-term (Bernet 2012a).

With respect to mass wasting, temperature warming would favour the desiccation of soils and the opening of cracks. However, the combination of temperature increase with erratic, huge rainfall may accelerate the downslope movement of landslides (either slumps or earthflows) with water penetrating deeper into the cracks. These processes may be reinforced locally by rapid snow cover melting and subsequent saturation of the shale bedrock underneath. In southernmost Mustang, an increasing monsoon influence is suggested by the latest GCMs (Immerzeel et al. 2013) which, if verified, would cause more gullying and debris-flow events (Figs. $6 \mathrm{~b}, 8 \mathrm{~b}$ ), these latter being reinforced by permafrost degradation (ground ice melting) when the tributary catchment is steep and extends to high elevations.

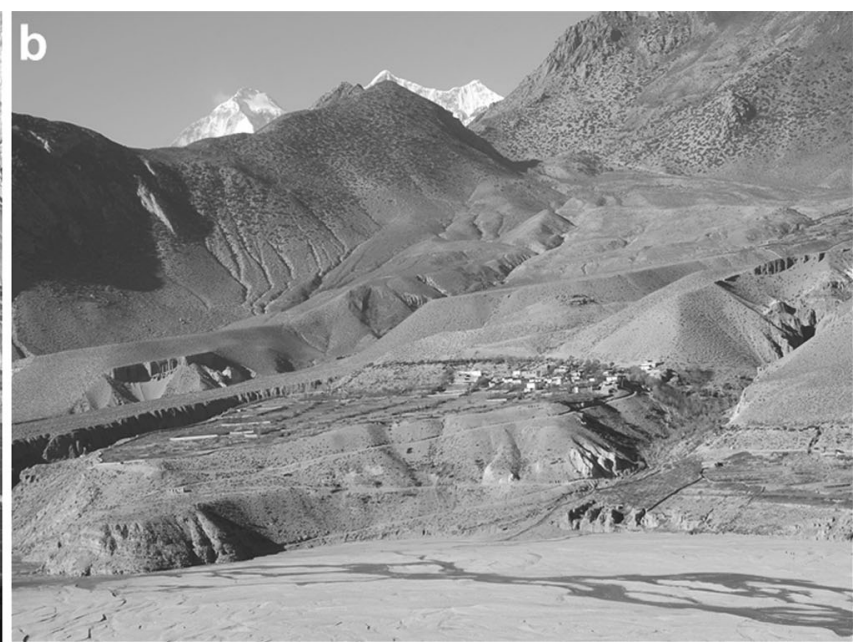

village $\left(28^{\circ} 49^{\prime}-83^{\circ} 45^{\prime} \mathrm{E}, 2,900 \mathrm{~m}\right.$ asl.) threatened by many natural hazards (gullying, mass wasting, flashfloods and undercutting by the Kali Gandaki River (see the eroded bank beneath the orchards in the right corner). The Dhaulagiri peak $(8,172 \mathrm{~m}$ asl.) is visible in the left background (@2009 M. Fort)

\section{Permafrost evolution}

Permafrost must also be considered as a source of water and a cause of mountain slope destabilization; yet studies on permafrost degradation remain limited to the upper Himalayan valleys and north of the Greater Himalaya (Fujii and Higuchi 1976; Matsuoka 1984; Shiraiwa 1992; Fukui et al. 2007; Regmi 2009). In the nearby QinghaiTibet Plateau, however, recent data recorded along the new railway crossing the eastern part of the plateau show that, for the last 15 years, the thickness of the active layer (the upper part of the ground that melts during the summer period) has increased, at a rate accelerating with time ( $\mathrm{Wu}$ et al. 2011). This clearly demonstrates the general warming of high elevation areas, as pointed out by IPCC (2007).

Ground ice is a hidden source of water in areas without permanent glacial ice (Xie et al. 2012), where elevations are lower than the glaciation limit; in a context of global warming, this non-renewable resource would be depleted and no longer available for the population living on the lower slopes. However, the amount of water provided during late summer might be an important contribution to discharge (Bookhagen 2012) and a good complement for local farmers or grazing grounds. In the higher areas (upper catchments), an increased depth in the permafrost active layer may also favour new slope instabilities, like earthflows with their potential downstream effects as suppliers of debris flows, the worst hazards threatening villages built on confluence fans (Syang, Marpha, Tukuche) with the Kali Gandaki River.

Acceleration of permafrost degradation might also affect the steepest rock walls; if periglacial erosion is quite 
common in high mountains (Heimsath and McGlynn 2008; Regmi and Watanabe 2009), rapid permafrost melting may cause rock avalanches, such as the north wall of Nilgiri Himal (7061 m asl.), which overlook the Kali Gandaki valley. With an altitudinal drop of more than $4,000 \mathrm{~m}$ in $<8 \mathrm{~km}$ in distance, such a collapse would certainly impact the nearby settlements of Thini $\left(28^{\circ} 46^{\prime} \mathrm{N}-83^{\circ} 43^{\prime} \mathrm{E}\right.$, $2,870 \mathrm{~m}$ asl.), Syang $\left(28^{\circ} 45^{\prime} \mathrm{N}-83^{\circ} 42^{\prime} \mathrm{E}, 2,730 \mathrm{~m}\right.$ asl.) and Jomosom, at 2,740 $\mathrm{m}$ asl. Moreover, such a process may also occur independently of any climate forcing, such as an effect of debuttressing of mountain slopes following deglaciation (see the $\approx 1,000$-year-old rock avalanche remnants still visible between Jomosom and Tukuche, as described in Fort 2000b and Fort 2011b). Nevertheless, the combination of these two, non-exclusive and favourable factors may presently increase the frequency and magnitude of mountain cliff instabilities.

Evidence of climate change as observed locally by its impacts on land use?

Anticipating future climate changes are difficult without good quality, long-term climate records. This is why it is interesting to compare observed and perceived impacts of climate change by the local population (Haffner et al. 2001; $\mathrm{Su}$ et al. 2013), which may provide a qualitative and indirect assessment of the water budget wherever quantitative data are lacking. For instance, in Marpha $(10 \mathrm{~km}$ south of Jomosom) where the Experimental Farm was established nearly 40 years ago by Pasang Sherpa, farmers experienced and perceived a rise in both summer and winter temperatures, together with changes in the intensity and timing of rainfall and the amount of snowfall (Su et al. 2013). These perceptions were validated by meteorological data established for the last 40 years, which show an increase of $0.52{ }^{\circ} \mathrm{C} / \mathrm{decade}$ of the annual average maximum temperature (Kattel and Yao 2013). More specifically, it appears that there is a good correlation between hailstorms and increasing minimum temperatures in the area. In addition to hailstorms, farmers reported the occurrence of other climatic shocks (erratic rainfall, decreasing snowfall, frost, fog) as responsible for the decline in their crop yields, tree crop yields and livestock production, eventually resulting in a loss of income ( $\mathrm{Su}$ et al. 2013). It seems that, whereas decreasing snow is certainly a good evidence of progressive warming (less water available for the developing crops in spring), the increasing amount and duration of rainfall has become a direct threat to traditional crops, as observed in summer 2007 (report by the District Agricultural Development Office Mustang, 2008, as cited in Su et al. 2013).

Climate change also seems to be partly the cause of pastureland degradation (loss of productivity) in the upper
Mustang valley, for instance in the extensive pastures of Ghiling $\left(28^{\circ} 57^{\prime}-29^{\circ} 03^{\prime} \mathrm{N}\right.$ and $\left.83^{\circ} 47^{\prime}-83^{\circ} 55^{\prime} \mathrm{E}\right)$ at $3500 \mathrm{~m}$ asl. east of Ghami. This degradation is assumed to be due to two main parameters, i.e. snow and winds (Paudel and Andersen 2010). Declining snow accumulation (thickness and duration) together with an irregular and shifting pattern of snowfall (from winter to early spring) are both in agreement with the experiences of local people who perceive snowfall as the major determinant for rangeland vegetation, whereas desiccating southerly winds may reinforce aridity on south-facing slopes. However, other causes for the deteriorating conditions of rangelands are suggested, like in eastern Mustang, where ongoing pressure on grazing resources is exacerbated along trafficking routes for animal trade from the TAR to the Nepal lowlands (Pokhara, Kathmandu) (Lama 2011).

The road linking the monsoon side to the upper arid zone of Mustang district is potentially a good option to help farmers and herders to find new sources of income. This road has led to changes in land use due to the new prospects it offers; fruit trees (mostly apple) have developed on any arable land available (mostly Quaternary terraces), and farmers have built water tanks accordingly (Fig. 9) to ensure a sufficient irrigation and hence sufficient yields and profit (in 2013, the price of $1 \mathrm{~kg}$ of apples $-120 \mathrm{NR}$ - is 20 times more than before the opening of the road, 6 years ago). Other income sources could be the development of ecotourism and sales of local livestock products, as advocated by Lama (2011) and Devkota (2011). For example, the road would offer visitors new destinations to observe the modes of life and culture of Loba herders living in their unique rangeland landscapes. It would also be a direct way to introduce manufactured products from China.

Nevertheless, this road, which either runs along the Kali Gandaki flood plain or climbs the steep cliffs cut into the fragile material of the Mustang graben would certainly be affected by any aggravation of natural hazards due to climate change (i.e. monsoon strengthening). More generally, the overall potential increase in natural hazards may lead to long-term road closure, jeopardizing the development of small markets and the connection of these upper valleys to the main urban centres of Nepal (Pokhara, Kathmandu), a country with a very low economic and social capacity to adjust (Fort 2011a).

Finally, potential conflicts may arise from an increased demand for water consumption and uses by different populations. Although farming and fruit-tree development seem to be sustainable with the construction of water tanks, and (eco)tourism is viewed by some inhabitants as a good way to reduce poverty, the latter may also contribute to the increasing stress on water resources, thus widening the gap between locals and visitors. 


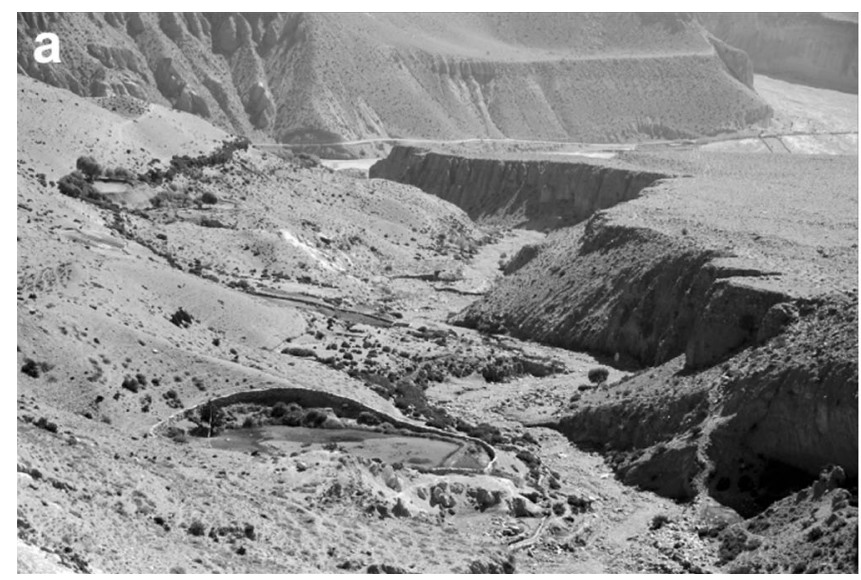

Fig. 9 a Downstream of Phyalak, new water tanks (left foreground and middle ground) have recently been built to sustain the irrigation canals running down the lower terrace of the Kali Gandaki

\section{Concluding remarks}

Climate warming may have specific impacts in the driest parts of the northern Himalayas, as illustrated by the Mustang case, where some observed evidence and a few meteorological data are available. Natural hazards already present will probably be exacerbated by changing patterns of temperature and precipitation, with less snow, shorter snow cover periods and more rainfall all being triggers for mass wasting, debris flow and gullying. Warming may also affect the glacierized areas (although the glaciation in this area is already very limited) and, more certainly, the permafrost belt, either seasonal or perennial. The predicted general decrease in water resources for irrigation and rangelands, upon which the survival of rural populations living in these remote places depends, would certainly conflict with new activities (tourism, road-induced trade and the small market economy) due to a higher water demand. Nevertheless, at this stage an exact ground water budget is not available, and the predicted economic development might be a more important factor than climate warming in generating water scarcity. All require appropriate adaptation measures, such as those already developed (water tanks), and an increasing awareness of the environmental fragility of Mustang in order to maintain its living potential and cultural heritage.

Acknowledgments Fieldwork was supported by various ParisDiderot University and CNRS (RCP Nepal, GRECO Himalaya, UMR 8586 PRODIG) research grants during the last 38 years. My warmest thanks go to my porters, and to the many friends and colleagues of Kathmandu Institutions (Department of Mines and Geology, TriChandra Campus Tribhuvan University, Kirtipur University, ICIMOD) for stimulating discussions and support. My appreciation goes to Carol Robins who helped improve the English, and to M. Pateau and V. Viel (Univ. Paris-Diderot) who helped for the figures. I also thank anonymous reviewers for their constructive remarks.

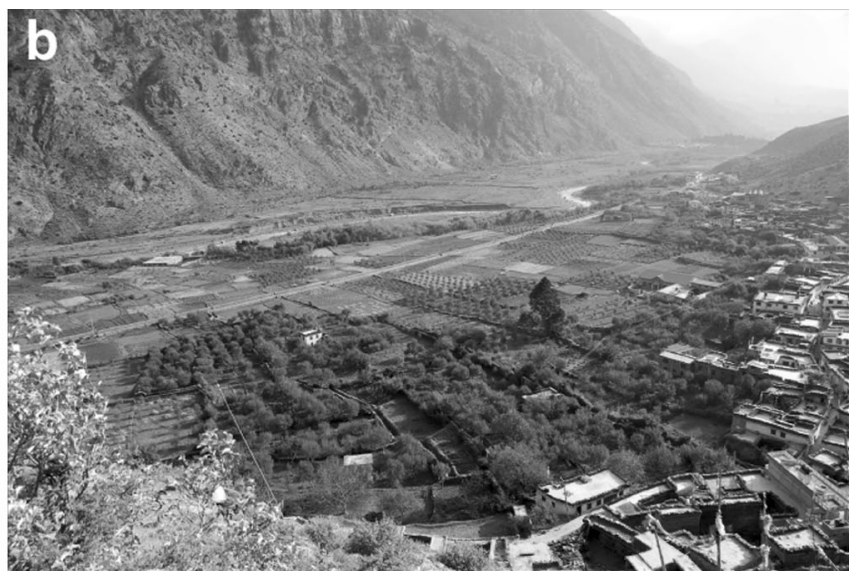

(background); b Marpha village (left) and its orchards which now occupy most of the lower terrace of the Kali Gandaki to the detriment of former cereal fields (@2013 M. Fort)

\section{References}

Baade J, Mäusbacher R (2000) Environmental change and settlement history, preliminary results from the Muktinath Valley, inner Himalayas, Nepal. Marburger Geogr Schriften 135: $40-52$

Baade J, Mäusbacher R, Wagner GA, Heine E, Kostka R (1998) Landslides and deserted places in the semi-arid environment of the inner Himalaya. In: Kalvoda J, Rosenfeld CL (eds) Geomorphological hazards in high mountain areas. Kluwer Academic Publishers, Dordrecht, pp 49-61

Bahadur KCK (2012) Spatio-temporal patterns of agricultural expansion and its effect on watershed degradation: a case from the mountains of Nepal. Environ Earth Sci 65(7):2063-2077. doi:10.1007/s12665-011-1186-6

Bajracharya S, Mool P (2009) Glaciers, glacial lakes and glacial lake outburst floods in the Mount Everest region, Nepal. Ann Glaciol 50-53:81-86

Bernet D (2012a) Moving down or not? Report of the first field visit to Upper Mustang in early May 2012 (Part II: Samzung). Unpublished internal report. Kam for Sud, Tathali, p 112

Bernet D (2012b) Moving down or not? Report of the first field visit to Upper Mustang in early May 2012 (Part III: Yara). Unpublished internal report. Kam for Sud, Tathali, p 77

Bolch T, Buchroithner MF, Peters J, Baessler M, Bajracharya S (2008) Identification of glacier motion and potentially dangerous glacial lakes in the Mt. Everest region/Nepal using spaceborne imagery. Nat Hazards Earth Syst Sci 8:1329-1340

Bookhagen B (2012) Himalayan groundwater. Nat Geosci 5:97-98

Bookhagen B, Burbank DW (2010) Towards a complete Himalayan hydrological budget: the spatiotemporal distribution of snowmelt and rainfall and their impact on river discharge. J Geophys Research 115:FO3019. doi:10.1029/2009JF001426

Devkota D (2011) Sustainable cross-border ecotourism strategy in the Tibetan Plateau region. In: Kreutzmann H, Yong Y, Tichter J (eds) Pastoralism and rangeland management on the Tibetan Plateau in the context of climate and global change. Deutsche Gesellschaft für Internationale Zusammenarbeit (GIZ) $\mathrm{GmbH}$, Germany, pp 123-141

Dobremez JF (1976) Le Népal. Écologie et Biogéographie. CNRS, Paris, p 363

Dobremez JF, Jest C (1971) Carte écologique du Népal I. Région Annapurna-Dhaulagiri. Doc Carte Végétation Alpes 9:147-190 
Dyurgerov M, Meier MF (2005) Glaciers and the changing earth system. A 2004 snapshot, Occasional Paper 58. Arctic and Alpine Research, University of Colorado, Boulder (Co), p 118

Fort M (1987) Geomorphic and Hazards mapping in the dry, continental Himalaya: 1:50,000 maps of Mustang District, Nepal. Mt Res Dev 7(3):222-238

Fort M (1996) Late Cenozoic environmental changes and uplift on the northern side of the Central Himalaya: a reappraisal from field data. Palaeoclimatol Palaeoecol Palaeogeogr 120:123-145

Fort M (1999) The role of large magnitude events in the distribution of natural hazards in the Nepalese Himalaya. In: Price M (ed) Global change in the mountains. Parthenon Publ, London, pp 169-171

Fort M (2000a) Natural conditions and hazards for irrigation in the arid Himalaya of Upper Mustang District, Nepal. In: Kreutzmann H (ed) Sharing Water. Oxford University Press, 239-258

Fort M (2000b) Glaciers and mass wasting processes: their influence on the shaping of the Kali Gandaki valley (Higher Himalaya of Nepal). Quatern Int 65/66:101-119

Fort M (2011a) The Himalayas: from mountain building to landform evolution in a changing world. A tribute to Professor L. Starkel. Geographia Polonica 84(2):15-37

Fort M (2011b) Two large late Quaternary rock slope failures and their geomorphic significance, Annapurna Himalayas (Nepal). Geografia Fisica Dinamica Quaternaria 34(1):5-14

Fort M, Freytet P, Colchen M (1982) Structural and sedimentological evolution of the Thakkhola-Mustang Graben (Nepal Himalaya). Zeit Geomorph N F 42:75-93

Fujii Y, Higuchi K (1976) Ground temperature and its relation to permafrost occurrences in the Khumbu Region and Hidden Valley: glaciological expedition to Nepal, contribution no. 26. J Jpn Soc Snow Ice 38:125-128

Fujita K, Sakai A, Takenaka S, Nuimura T, Surazakov AB, Sawagaki T, Yamanokuchi T (2013) Potential flood volume of Himalayan glacial lakes. Nat Hazards Earth Syst Sci 13:1827-1839

Fukui K, Fujii Y, Ageta Y, Asahi K (2007) Changes in the lower limit of mountain permafrost between 1973 and 2004 in the Khumbu Himal, the Nepal Himalayas. Glob Planet Change 55:251-256

Gurung HB (1980) Vignettes of Nepal. Sahayogi Press, Kathmandu, p 435

Haffner WU, Benachib H, Brock C, Gerique A, Merl K, Morkel S, Park M, Pohl, P, Titz AUK, Werding K (2001) Geographical field studies in Southern Mustang/Kali Gandaki Valley (Sept./ Oct. 2000). In: Proceedings of the International Conference in Kathmandu: Sustainable Management of Natural and Human Resources in South Asia

Heimsath AM, McGlynn R (2008) Quantifying periglacial erosion in the Nepal high Himalaya. Geomorphology 97:5-23

Hewitt K (2005) The Karakoram anomaly? Glacier expansion and the elevation effect, Karakoram Himalaya. Mt Res Dev 25:332-340

ICIMOD (2011) Glacial lakes and glacial lake outburst floods in Nepal. ICIMOD, Kathmandu, p 99

Immerzeel WW, van Beek LPH, Bierkens MFP (2010) Climate change will affect the Asian Water Towers. Science 328(5984): 1382-1385

Immerzeel WW, Pellicciotti F, Bierkens MFP (2013) Rising river flows throughout the twenty-first century in two Himalayan glacierized watersheds. Nat GeoSci 6:742-745. doi:10.1038/ NGEO1896

IPCC (2007) Climate change 2007 synthesis report: summary for policymakers. Published online at www.ipcc.ch/pdf/assessmentreport/ar4/syr/ar4_syr_spm.pdf

Kappenberger G (2007) Climate changes and mountains. In: Baudo R, Tartarini G, Vuillermoz E (eds) Mountains witnesses of global changes. Elsevier, Amsterdam, pp 133-143
Kattel DB, Yao T (2013) Recent temperature trends at mountain stations on the southern slope of the central Himalayas. J Earth Syst Sci 122(1):215-227

Knörtzer KH (2000) 3000 years of agriculture in a valley of the High Himalayas. Veg Hist Archaeobot 9:219-222

Kundzewicz ZW, Merz B, S. Vorogushyn S, Hartmann H, Duethmann D, Wortmann M, Huang S, Su B, Jiang T, Krysanova V (2014) Observed changes in climate and river discharge in the Aksu River Basin. Environ Earth Sci (this issue). doi:10.1007/ s12665-014-3137-5

Lama N (2011) Rangeland management and eco-tourism. In: Kreutzmann H, Yong Y, Tichter J (eds) Pastoralism and rangeland management on the Tibetan Plateau in the context of climate and global change. Deutsche Gesellschaft für Internationale Zusammenarbeit (GIZ) GmbH, Germany, pp 87-101

Lioubimtseva E (2013) A multi-scale assessment of human vulnerability to climate change in the Aral Sea Basin. Environ Earth Sci. doi:10.1007/978-3-642-02356-9_17

Matsuoka N (1984) Frost shattering of bedrocks in the periglacial regions of the Nepal Himalaya. Seppyo 46:19-25

McSweeney C, New M, Lizcano G (2010) UNDP climate change country profile: Nepal. http://www.climatenepal.org.np/main/ $? \mathrm{p}=$ research\&sp $=$ onlinelibrary\&opt $=$ detail $\& \mathrm{id}=372$

Messerli B, Ives JD (eds) (1997) Mountains of the world: a global priority. Parthenon, London

Miehe G (1984) Vegetationsgrenzen im extremen und multizonalen Hochgebirge (Zentraler Himalaya). Erdkunde 38:268-277

Miehe G, Miehe S, Schlütz F (2002) Vegetationskundliche und Palynologische Befunde aus dem Muktinath-Tal (Tibetischer Himalaya, Nepal). Ein Beitrag zur Landschaftsgeschichte altweltlicher Hochgebirgshalbwüsten. Erdkunde Band 56:268-285

Miehe G, Miehe S, Schlütz F (2009) Early human impact in the forest ecotone of southern High Asia (Hindu Kush, Himalaya). Quatern Res 71:255-265

Miller JD, Immerzeel WW, Rees G (2012) Climate change impacts on Glacier hydrology and river discharge in the Hindu KushHimalayas. Mt Res Dev 32(4):461-467. doi:10.1659/MRDJOURNAL-D-12-00027.1

Mool PK, Bajracharya SR, Joshi SP (2001) Inventory of glaciers, glacial lakes and glacial lake outburst floods, Nepal. ICIMOD and UNEP/RRC-AP, Kathmandu, p 363

New M, Lister D, Hulme M et al (2002) A high-resolution data set of surface climate over global land areas. Clim Res 21(1):1-25

Paudel KP, Andersen P (2010) Assessing rangeland degradation using multi temporal satellite images and grazing pressure surface model in Upper Mustang, Trans Himalaya, Nepal. Remote Sens Environ 114:1845-1855

Pohle P (1993) Geographical research in the history of the cultural landscape of Southern Mustang. Ancient Nepal 134:58-88

Regmi D (2009) Rock Glacier distribution and the lower limit of discontinuous mountain permafrost in the Nepal Himalaya. In: Proceedings of the Ninth International Conference on Permafrost (NICOP), June 29-July 3, 2008, Alaska Fairbanks, pp 14751480

Regmi D, Watanabe T (2009) Rockfall activities in the Kangchenjunga Area, Nepal Himalaya. Permafrost Periglac Process 20:390-398

Schuh D (1992-93) Introduction. Ancient Nepal 130-133

Shiraiwa T (1992) Freeze thaw activities and rock breakdown in the Langtang valley, Nepal Himalaya. Environ Sci 15:1-12

Shrestha AB (2009) Climate change in the Hindu Kush-Himalayas and its impacts on water and hazards. APMN (Asia Pacific Mountain Network) Bulletin 9:1-5

Shrestha A, Aryal R (2011) Climate change in Nepal and its impact on Himalayan glaciers. Reg Environ Change 11(Suppl 1):65-77 
Simons A, Schön W (1998) Cave systems and terrace settlements in Mustang, Nepal. Settlement periods from prehistoric times to the present day. Beiträge zur allgemeinen und vergleichenden Archäologie 18:27-47

Simons A, Schön W, Dämmer HW (1997) Mit dem Seil in die Vergangenheit. Archäologie im Hohen Himalaja. Forschung Mittelungen DFG 2-3(97):30-34

Singh SP, Bassignana-Khadka I, Karky BS, Sharma E (2011) Climate change in the Hindu Kush-Himalayas: The state of current knowledge. ICIMOD, Kathmandu

Su Y, Lu J, Manandhar S, Ahmad A, Xu J (2013) Policy and institutions in adaptation to climate change. Case study on tree crop diversity in China, Nepal, and Pakistan. ICIMOD Working Paper 2013/3, Kathmandu: ICIMOD, p 60
Thayyen RJ, Gergan JT (2010) Role of glaciers in watershed hydrology: a preliminary study of a "Himalayan catchment". Cryosphere 4:115-128

von Fürer-Haimendorf C (1975) Himalayan traders. J. Murray, London, p 315

Wu Q, Zhang T, Liu Y (2011) Thermal state of the active layer and permafrost along the Qinghai-Xizang (Tibet) Railway from 2006 to 2010. Cryosphere 6:607-612. doi:10.5194/tc-6-607-2012

Xie C, Zhao L, Wu T, Dong X (2012) Changes in the thermal and hydraulic regime within the active layer in the Qinghai-Tibet Plateau. J Mt Sci 9:483-491 